\title{
The biological activities of $\beta$-glucosidase, phosphatase and urease as soil quality indicators: a review
}

\author{
Adewole T. Adetunji ${ }^{1}$, Francis B. Lewu ${ }^{2 *}$, Reckson Mulidzi ${ }^{3}$, Bongani Ncube ${ }^{2}$
}

${ }^{1}$ Department of Environmental and Occupational Studies, Cape Peninsula University of Technology, P.O. Box 652, Cape Town 8000. South Africa. ${ }^{2}$ Department of Agriculture, Cape Peninsula University of Technology, Wellington 7655, Western Cape, South Africa. ${ }^{3}$ ARC Infruitec-Nietvoorbij, Private Bag X5026, Stellenbosch 7599, South Africa.

*Corresponding author: lewuf@cput.ac.za

\begin{abstract}
Soil is a fundamental resource and it is crucial to manage its quality in order to enhance agricultural productivity and environmental quality. Soil enzymes catalyze several biochemical reactions which result in the transformation of organic matter, and the release of inorganic nutrients for plant growth and nutrient cycling. Soil enzyme activities are useful biological soil quality indicators since they are operationally practical, very sensitive, integrative, easy to measure and more responsive to soil tillage and structure than other soil variables. There are several enzymes in soil, but those involved in hydrolases and the degradation of main litter components are used most often for evaluating soil quality. This paper reviews the roles of soil enzymes such as $\beta$-glucosidase, phosphatase and urease, as well as the implications of their activities for soil quality.
\end{abstract}

Keywords: Decomposition, enzyme activity, phosphatase, soil quality, urease, $\beta$-glucosidase

\section{Introduction}

The soil is a living, dynamic and non-renewable resource. Soil conditions influence food production, environmental efficiency and the global ecological balance (Binkley and Fisher, 2012). Soil quality is an important indicator of good crop yield in various land use contexts (Almeida et al., 2015). Doran and Parkin (1994) define soil quality as 'the continued capacity of soil to function as a vital living system, within ecosystem and land use boundaries, to sustain biological productivity, promote the quality of air and water environments and maintain plant, animal and human health'. To manage soil quality, it is essential to have appropriate tools for predicting and evaluating soil changes 
caused by various management practices and environmental factors (Piotrowska and Wilczewski, 2012). A number of methods have been used to predict changes in soil quality. The chemical, physical and biological properties of soil can serve as indicators of quality (Abbott and Murphy, 2003). Indicators that are sensitive and make rapid, incisive and efficient responses concerning soil quality are preferred (Matsuoka et al., 2003). Soil quality indicators that are linked to microbial activity may respond to disturbances over a shorter period of time than those linked to physical or chemical properties (Garcia-Gil et al., 2000). Thus, soil ecosystem sustainability can be suitably evaluated through the use of biologically-based indicators (Piotrowska-Dlugosz and Charzynski, 2015).

In recent years, soil biology has turned to assessing the degrading capacity of microorganisms by evaluating their enzyme activity (Fioretto et al., 2000). Microbial species release enzymes into the environment in order to degrade complex organic molecules into absorbable simple molecules (Almeida et al., 2015). Thus, soil enzymes catalyze and increase several biochemical reactions (Gianfreda, 2015) that bring about the decay of organic residues, transformation of native soil organic matter, mineralization of nutrients for plant growth, and soil aggregation (Balezentiene, 2012). Decomposition rates are therefore linked to the enzymes that act directly on the main structural parts of plant material and can supply useful information on definite features of the microbial community and succession (Fioretto et al., 2000). This paper reviews the properties and roles of three enzymes - $\beta$-glucosidase, phosphatase and urease - as indicators of soil quality. It also reviews the factors affecting their activity in the soil as well as their application in agriculture.

\section{General characteristics and use of soil enzymes}

All soils contain a group of intracellular and extracellular enzymes with different origins that may be synthesized by plants, animals, and microorganisms (Gianfreda et al., 1996; Verdoucq et al., 2003). Intracellular enzymes can be found in various parts of proliferating living cells (Nannipieri et al., 1998). Living cells, however, produce and secrete extracellular enzymes which function outside the parent cells as free enzymes in a soil solution or as enzymes that are still associated with the external surface of the root epidermal or microbial cell wall (Gianfreda, 2015). These enzymes are not only available in dead cells, but may also be taken up on clays or integrated into humic substances. Enzymes play a vital role in agriculture and in nutrient cycling, in particular, since they are constantly being synthesized, accumulated, inactivated and decomposed in the soil (Balota and Chaves, 2010).

The choice to use enzymes to assess soil quality is based on their sensitivity to soil management, organic matter decomposition, and relative ease of analysis (Balota and Chaves, 2010). The determination of soil fertility and plant yield using a single enzyme activity has been proven to be inaccurate (Nannipieri et al., 2012). This is because soil enzyme activities catalyze a particular reaction and cannot therefore be linked to the general soil microbiological activity, which comprises a wide range of different enzymatic reactions (Nannipieri et al., 2012). Furthermore, a given enzyme cannot reflect the whole nutrient status of the soil because it is substrate specific (Nannipieri et al., 2012). Thus the enzymes most widely used for evaluating the factors controlling plant litter decomposition and soil quality are those involved in the degradation of main litter components and 
hydrolases, which are associated with the carbon (C) ( $\beta$-glucosidase and $\beta$-galactosidase), nitrogen (N) (urease), phosphorus (P) (phosphatase) and sulphur (S) (arylsulphatase) cycle (Karaca et al., 2010). Other soil enzymes may include amylase, amidase, phenol oxidase, cellulose, chitinase, de hydrogenase and protease (Karaca et al., 2010, Tabatabai, 1994). Table 1 shows some of the common soil enzymes that can be used as biological soil quality indicators.

Table 1. Soil enzymes as indicators of soil quality

\begin{tabular}{|c|c|c|c|}
\hline Soil enzyme & Enzyme reaction & Reaction catalyzed & $\begin{array}{l}\text { Indicator of } \\
\text { microbial } \\
\text { activity }\end{array}$ \\
\hline Dehydrogenase & $\begin{array}{l}\text { Electron transport } \\
\text { system }\end{array}$ & $\mathrm{XH}_{2}+\mathrm{A} \rightarrow \mathrm{X}+\mathrm{AH}_{2}$ & C-cycling \\
\hline$\beta$-glucosidase & $\begin{array}{l}\text { Cellobiose } \\
\text { hydrolysis }\end{array}$ & $\begin{array}{l}\text { Glucoside }+\mathrm{H}_{2} \mathrm{O} \rightarrow \mathrm{ROH}+ \\
\text { glucose }\end{array}$ & C-cycling \\
\hline Cellulase & $\begin{array}{l}\text { Cellulose } \\
\text { hydrolysis }\end{array}$ & $\begin{array}{l}\text { Hydrolysis of } \beta-1,4 \text { - glucan } \\
\text { bonds }\end{array}$ & C-cycling \\
\hline Phenol oxidase & Lignin hydrolysis & $\mathrm{A}+\mathrm{H}_{2} \mathrm{O}_{2} \rightarrow$ oxidized $\mathrm{A}+\mathrm{H}_{2} \mathrm{O}$ & C-cycling \\
\hline Urease & Urea hydrolysis & $\mathrm{Urea} \rightarrow 2 \mathrm{NH}_{3}+\mathrm{CO}_{2}$ & $\mathrm{~N}$-cycling \\
\hline Amidase & $\mathrm{N}$-mineralization & $\begin{array}{l}\text { Carboxylic acid amide }+\mathrm{H}_{2} \mathrm{O} \rightarrow \\
\text { carboxylic acid }+\mathrm{NH}_{3}\end{array}$ & $\mathrm{~N}$-cycling \\
\hline Protease & $\mathrm{N}$-mineralization & $\begin{array}{l}\text { Proteins } \rightarrow \text { peptides and amino } \\
\text { acids }\end{array}$ & $\mathrm{N}$-cycling \\
\hline Phosphatase & Release of $\mathrm{PO}_{4}^{-}$ & $\begin{array}{l}\text { Phosphate ester }+\mathrm{H}_{2} \mathrm{O} \rightarrow \mathrm{ROH} \\
\text { phosphate }\end{array}$ & P-cycling \\
\hline Arylsulphatase & Release of $\mathrm{SO}_{4}^{-}$ & $\mathrm{ROSO}_{3}{ }^{-}+\mathrm{H}_{2} \mathrm{O} \rightarrow \mathrm{ROH} \mathrm{SO}_{4}{ }^{-2}$ & S-cycling \\
\hline $\begin{array}{l}\text { Other soil } \\
\text { enzymes }\end{array}$ & Hydrolysis & Hydrolysis & $\begin{array}{l}\text { General organic } \\
\text { matter } \\
\text { degradative } \\
\text { enzyme activities }\end{array}$ \\
\hline
\end{tabular}


Soil enzyme activity can be estimated and serve as a valuable pointer to nutrient cycling potential, nitrification, oxidation, and other processes crucial to soil quality (Almeida et al., 2015). This review therefore focuses on the enzymes $\beta$-glucosidase, phosphatase and urease, known to play crucial roles in $\mathrm{C}, \mathrm{P}$ and $\mathrm{N}$ cycling respectively, which are important nutrients for plant growth and microbial metabolism. The three enzymes are widely distributed in nature and are very sensitive to the environment and managementinduced changes in the soil ecosystem.

\section{3. $\beta$-Glucosidases}

\subsection{Characteristics and role of $\beta$-glucosidases}

Glycosidases are a group of enzymes that catalyze the hydrolysis of glycosides (Martinez and Tabatabai, 1997). They are highly diverse enzymes owing to the wide diversity of glycosidic bonds and variations in their substrates (Almeida et al., 2015). Among the glycosidases, $\alpha$ - and $\beta$-glucosidase, as well as $\alpha$ - and $\beta$-galactosidase are the main members, widely distributed in the soil (Utobo and Tewari, 2015). The $\alpha$-glucosidase (maltase) catalyzes the hydrolysis of $\alpha$-D-glucopyranosides while $\beta$-glucosidase (cellobiase) hydrolyzes maltose and cellobiose (Utobo and Tewari, 2015). $\beta$-glucosidase is, however, the most common, important and widely used soil quality indicator (Bandick and Dick, 1999).

$\beta$-glucosidase is predominantly found among plants, animals, fungi, bacteria, and yeasts (Veena et al., 2011). Its role in soils is crucial since it is involved in catalyzing the hydrolysis and biodegradation of various $\beta$-glucosides that are present in plant debris (Martinez and Tabatabai, 1997). $\beta$-glucosidase acts in the last phase of the cellulose degradation process by hydrolyzing the cellobiose residue (Gil-Sotres et al., 2005). These reactions produce glucose as the final product, an important $\mathrm{C}$ energy source for the growth and activity of soil microorganisms (Merino et al., 2016). $\beta$-glucosidase's involvement in C cycling has remarkably facilitated its adoption for soil quality testing.

\subsection{Factors affecting $\beta$-glucosidase activity}

The activity of $\beta$-glucosidase decreased as soil $\mathrm{pH}$ increased from 4.5 to 8.5 (Eivazi and Tabatabai, 1990), and 4.3 to 7.4 in a paddy soil (Xiao-Chang and Qin, 2006). The sensitivity of $\beta$-glucosidase to $\mathrm{pH}$ changes can serve as a reliable biochemical indicator for assessing environmental changes caused by soil acidification (Acosta-Martinez and Tabatabai, 2000).

Soil moisture can influence the biochemical processes of soil carbon transformation catalyzed by $\beta$-glucosidase (Zhang et al., 2011). $\beta$-glucosidase activity decreased by $10-80 \%$ and $35-83 \%$ when soil moisture was reduced by $10 \%$ and $21 \%$ respectively, depending on the soil depth (Sardans and Penuelas, 2005). Thus drought influences $\beta$-glucosidase activity and its catalytic features, causing a slower nutrient turnover and a reduced nutrient supply to plants.

Increased soil salinity and solidity led to an exponential and linear decline in $\beta$-glucosidase activity, respectively (Rietz and Haynes, 2003). It has been reported that plant residues in a soil polluted with heavy metals neither decompose nor indicate $\beta$-glucosidase activities (Geiger et al., 1993), resulting in less glucose for soil microbes. The response of $\beta$-glucosidase activity to soil salinity and heavy metal contamination can serve as a good pointer to soil quality status.

Several studies have revealed that $\beta$-glucosidase activity decreases with soil depth (Acosta-Martinez et al., 2003a; Xiao-Chang and Qin, 2006). This is because $\beta$-glucosidase activity greatly depend on substrate supply and the microorganisms that mainly produce this enzyme are active in the top soil (Xiao-Chang and 
Qin, 2006). Therefore, $\beta$-glucosidase activity can be used to indicate the presence of higher simple sugars for microbial population in the soil surface layer.

\subsection{Application of $\beta$-glucosidase activity in agriculture}

The activity of $\beta$-glucosidase is influenced by crop residue quality and a number of soil management practices. A no-till system and reduction in tillage frequency results in an increase in the activities of $\beta$-glucosidase as well as microbial biomass $\mathrm{C}$ and $\mathrm{N}$ in contrast to a conventional tillage system (Pandey et al., 2014). The reduction in tillage intensity favors and increases $\beta$-glucosidase activity due to improvement in microbial biomass, more substrate availability and reduced soil disturbance (Sinsabaugh et al., 2008). Therefore, a conventional tillage system may cause soil organic matter depletion (Miralles et al., 2012), which can result in a reduction in simple sugars for microbial functioning owing to a decrease in $\beta$-glucosidase activity.

The activity of $\beta$-glucosidase was reported to be lower in arable soils than in woodland and meadow soils (Bandick and Dick, 1999). This may be as a result of varying substrate and organic matter composition associated with each soil. Incorporation of residues of vetch, oat+legume, Trifolium pratense L, Brassica napus L and Trifolium pratense $\mathrm{L}+$ Brassica napus $\mathrm{L}$, led to an increase in the activity of $\beta$-glucosidase compared to oats (Mukumbareza et al., 2015; Piotrowska-Dlugosz and Wilczewski, 2014a). $\beta$-glucosidase activity increased because the soils amended with lower $\mathrm{C}: \mathrm{N}$ crop residue favors its function, resulting in quick organic matter decomposition and nutrient release. The high capacity to respond to substrate and soil type make $\beta$-glucosidase activity an efficient soil quality indicator.
Several studies have shown that $\beta$-glucosidase activity was higher in fertilization treatments with compost, vermicompost, municipal solid waste compost and straw mulch, than in those without compost as well as those with synthetic fertilizer and herbicide (Crecchio et al., 2004; Meyer et al., 2015; Saha et al., 2008). Furthermore, $\beta$-glucosidase activity increased remarkably in various soils amended with sewage sludge and irrigated with winery wastewater rather than municipal water (Kizilkaya and Bayrakli, 2005, Mulidzi and Wooldridge, 2016). $\beta$-glucosidase activity increased due to the inducement caused by the addition of simple organic substrates contained in those residues, which makes this enzyme a reliable indicator of soil quality.

In general, $\beta$-glucosidase activity is closely related to soil organic matter, biological activity and $\mathrm{C}$ cycling, and it can provide an advanced sign of alterations in organic carbon long before this can be correctly determined by other routine techniques. These qualities have significantly enabled its adoption for soil quality testing in agriculture. More knowledge is however needed to show the dynamics of $\beta$-glucosidase and other factors influencing their activity, to enhance the understanding of biological soil fertility management in agriculture.

\section{Phosphatases}

\subsection{Characteristics and role of phosphatases}

Phosphatases are a group of enzymes that catalyze the hydrolysis of esters and anhydrides of phosphoric acid (Condron et al., 2005). Plants and microorganisms are the main sources of phosphatase enzymes in the soil. The amount of phosphatase present in the soil varies with the microbial count and the extent of organic materials, mineral and organic fertilizers, 
tillage and other agricultural practices (Banerjee et al., 2012).

Since plants make use of only inorganic $\mathrm{P}$ and a large amount of soil $\mathrm{P}$ is organically bound, the mineralization of this organic portion can be a vital influence in plant nutrition (Nannipieri et al., 2011). When phosphorus is lacking in the soil, plant roots and microorganisms increase the secretion of phosphatase to intensify the solubilization and remobilization of phosphate, therefore influencing the ability of the plant to cope with phosphorus-stressed conditions (Kai et al., 2002). This shows that the demand for phosphorus by plants and microorganisms can be linked to the production and activity of soil phosphatase (Condron et al., 2005). Phosphatase activity can therefore be used as an indicator of inorganic phosphorus availability for plants and microorganisms (Piotrowska-Dlugosz and Charzynski, 2015).

Phosphomonoesterase is the most studied among the phosphatases present in the soil. It hydrolyses phosphate monoester to produce free phosphate for biological uptake (Makoi and Ndakidemi, 2008). Phosphomonoesterase is active under acidic and alkaline conditions, depending on its optimal $\mathrm{pH}$, and acts upon low molecular $\mathrm{P}$ compounds with monoester bonds, including nucleotides, sugar phosphates and polyphosphates (Dodor and Tabatabai, 2003). Acid phosphatase activity is therefore found mainly in acid soils, while alkaline phosphatase dominates in alkaline soils (Dodor and Tabatabai, 2003), with ranges of 4-6 and 9-11, respectively.

\subsection{Factors affecting phosphatase activity}

Soil $\mathrm{pH}$ influences the rate of synthesis, release, and stability of phosphatase (Acosta-Martinez and Tabatabai, 2000). As the soil pH increases, the activity of alkaline phosphatase increases, while acid phosphatase activity decreases (Dick et al., 2000). Alkaline (Pal) and acid (Pac) phosphatase activities can be used to examine the optimum soil $\mathrm{pH}$ for crop production and the amount of lime required to achieve it (Dick et al., 2000). Thus, determination of the $\mathrm{Pal} / \mathrm{Pac}$ ratio may be a better way of evaluating the effective soil $\mathrm{pH}$ and liming needs than the chemical method (Acosta-Martinez et al., 2003b).

The activity of phosphatase was influenced in soils affected by forest fire, increasing over the years as the soil recovered (Staddon et al., 1998). The effect of drought has also been reported: when soil moisture was reduced by $21 \%$, there was a $31-40 \%$ reduction in acid phosphatase activity (Sardans and Penuelas, 2005). The presence of lead and other heavy metals in the soil decreased phosphatase activity (Kandeler et al., 1996). Phosphatases are a good soil quality indicator since their activity reflects the situation of the soil.

\subsection{Application of phosphatase activity in agriculture}

In agricultural soils, phosphatases play a crucial role in phosphorus cycles, and because their activity is sensitive to management practices they can be used as an index of soil quality (Makoi and Ndakidemi, 2008). To improve soil quality management and agricultural productivity, it is important to evaluate the effect of different management practices on phosphatase activity in the soil. Agricultural management methods responsible for phosphorus stress in the soil may influence the production of these enzymes in the ecosystem (Ndakidemi, 2006).

Previous studies have reported that legumes such as chickpea, cowpea, Cyclopia and Aspalathus release more phosphatase enzymes than non-legumes (Liu et al., 2004; Makoi et al., 2010; Maseko and Dakora, 2013). This is because legumes require more phosphorus in the symbiotic nitrogen fixation process than cereals do (Makoi and Ndakidemi, 2008). The 
increase in phosphatase activity in the legume roots and soils leads to a significant increase in plant available P (Makoi et al., 2010). Thus, phosphorus supply and assimilation can be estimated by acid and alkaline phosphatase activity in the low-P soils of legume crops (Maseko and Dakora, 2013).

The activity of phosphatases was higher in a crop rotation system comprising oats or meadow than in a monoculture system of corn or soybean (Dodor and Tabatabai, 2003). Mukumbareza et al. (2015) revealed that the rotation of maize with vetch and fertilized oat cover crops increased microbial biomass carbon and the activities of phosphatase in a South African deep alluvial soil. The increased microbial biomass carbon and phosphatase activity in the bicultures as compared to the monocultures showed that the cover crops have synergistic effects in bicultures, and could be valuable for improving $\mathrm{P}$ cycling and soil physiochemical properties (Mukumbareza et al., 2016). Acid and alkaline phosphatase activity increased under various soil management practices where organic fertilizers like plant residues, sewage sludge, manure, compost and vermicompost were applied (Criquet et al., 2007; Nannipieri et al., 2011; Piotrowska-Dlugosz and Wilczewski, 2014b).

The increase in phosphatase activity associated with soils amended with organic materials can be attributed to stimulation of microbial growth and soil organic matter enrichment. Phosphatase activity can be considered to be a good index of the quality and quantity of organic matter in soils.

Several studies have reported that the activity of phosphatases increases in soils supplemented with organic matter and inoculated with mycorrhizal species (Joner and Jakobsen, 1995; Van Aarle and P1assard, 2010). The association of mycorrhizal with phosphatase activity supports the role this enzyme plays in the degradation of soil-bound phosphorus (Van Aarle and Plassard, 2010).
Phosphatase probably requires a considerable amount of $\mathrm{N}$, since nitrogen fertilization has been shown to increase acid phosphatase activity and reduced alkaline phosphatase activity in soils cultivated with corn and wheat (Kalembasa and Symanowicz, 2012; Lemanowicz, 2011). Furthermore, the joint application of vermicompost or municipal solid waste compost and mineral $\mathrm{N}$ fertilizer revealed higher phosphate activity than the separate application of the fertilizers to soil (Crecchio et al., 2004; Srivastava et al., 2012). Phosphatase activity increased when $\mathrm{P}$ fertilizer was added to soils with low organic matter, yet there were no changes in the activity of this enzyme when $P$ fertilizer was amended with soils containing high organic matter (Piotrowska-Dlugosz and Wilczewski, 2014a). Thus, the synthesis and activity of phosphatase can be influenced by $\mathrm{P}$ from mineral fertilization in the soil (Saha et al., 2008). This confirms that phosphatase increases the available reserves of $\mathrm{P}$ when this nutrient is limited, and that the addition of $\mathrm{P}$ to the soil is an alternative for increasing the availability of this element (Bautista-Cruz and Ortiz-Hernandez, 2015). Phosphatase activity can therefore serve as a good soil quality indicator because of its strong correlation with soil organic matter, organic $\mathrm{P}$, inorganic $\mathrm{P}$, and $\mathrm{N}$ availability in the soil.

No-tillage and conventional tillage systems affect soil biological activity and aggregate stability. Greater acid phosphatase activity was observed under a no-till and reduced tillage system compared to a continuous tillage system in Brazilian Cerrado Oxisol and rice grown soil (Green et al., 2007; Pandey et al., 2014). Thus, phosphatase activity is a reliable soil quality indicator since it promptly detects changes in soil organic matter caused by tillage. Tillage should be reduced to increase the biological activity of surface soils in order to improve P nutrient cycling processes and soil structure. 
A larger amount of the inorganic $\mathrm{P}$ assimilated by plants is produced from the mineralization of organic P through phosphatase activity. The functions of phosphatase activity and its ability to rapidly detect management changes, as described above, indicate the importance of this enzyme as a biological soil quality indicator. More understanding of the roles of phosphatase and better ways of optimizing its activities in soils managed organically will result in improved soil conservation, $\mathrm{P}$ release and increased agricultural sustainability in the ecosystems.

\section{Urease}

\subsection{Characteristics and role of Urease}

The urease enzyme acts by aiding the hydrolysis of urea into $\mathrm{CO}_{2}$ and $\mathrm{NH}_{3}$, which leads to a rise in soil $\mathrm{pH}$ and nitrogen loss to the atmosphere through $\mathrm{NH}_{3}$ volatilization (Das and Varma, 2010). Urease also catalyzes the hydrolysis of hydroxyurea, dihydroxyurea, and semicarbazide, with nickel as a co-factor (Alef and Nannipieri, 1995). The enzyme is widely distributed in nature, and it originates from bacteria, yeasts, fungi, algae, animal waste and plants (Follmer, 2008). Although urease may be constitutively synthesized in some organisms, its expression is usually under $\mathrm{N}$ regulation (Machuca et al., 2015). The synthesis of the enzyme is prevented when cells grow in the presence of $\mathrm{NH}_{4}^{+}$as the preferred $\mathrm{N}$ source (Geisseler et al., 2010). However, the presence of urea or an alternative $\mathrm{N}$ source activates urease production (Mobley et al., 1995). Studies of soil urease activity have been of great interest over the years and have been used as good index of soil quality, because of the role of urease in the regulation of $\mathrm{N}$ supply to plants after urea fertilization (Piotrowska-Dlugosz and Charzynski, 2015).

\subsection{Factors affecting urease activity}

The stability of urease depends on several factors, including soil moisture and temperature. Urease activity increases with increasing temperature, showing the effect of temperature on urease hydrolysis (Machuca et al., 2015). In addition, a grassland soil incubated over a range of temperatures $\left(-2\right.$ to $\left.21^{\circ} \mathrm{C}\right)$ showed a positive relationship between urease activity and temperature, with an activation energy $\left(\mathrm{E}_{\mathrm{a}}\right)$ of $73.4 \mathrm{~kJ} \mathrm{~mol}^{-1}$ and temperature coefficient $\left(\mathrm{Q}_{10}\right)$ of 2.78 (Fraser et al., 2013). Urea fertilizer should therefore be applied to the soil when the temperature is low and activation energy is low, to minimize the loss of $\mathrm{N}$ by the volatilization process (Makoi and Ndakidemi, 2008). Studies examining the temperature sensitivity of urease activity in soils will enhance knowledge of $\mathrm{N}$ cycling.

The reduction of soil moisture by $10 \%$ and $21 \%$ led to reductions of $10-67 \%$ and $42-62 \%$ in urease activity, respectively, which explains the link between drought and a slower nutrient turnover (Sardans and Penuelas, 2005). Yang et al. (2006) investigated the combined effects of cadmium, zinc and lead on urease activities and concluded that urease is very sensitive to toxic concentrations of heavy metals. The highest urease activity was recorded under soil water $\mathrm{pH} 5.8$ and the lowest activity at soil water pH 4.2 (Blonska and Lasota, 2014). The response of urease activity to drought, contamination and $\mathrm{pH}$ can be used to assess soil quality status.

\subsection{Application of urease activity in agriculture}

Urease activity has been widely used to monitor soil quality because it is influenced by different agricultural management practices (Blonska 
and Lasota, 2014; Corstanje et al., 2007). Urease activity increased in a soil management system where maize was rotated with vetch and fertilized oat cover crops, which led to an increase in maize yield (Mukumbareza et al., 2015). The high urease activity recorded in soils treated with vetch and a combination of vetch and oats indicates a greater potential for $\mathrm{N}$ cycling through a lower $\mathrm{C}: \mathrm{N}$ ratio. The activity of urease increases with organic fertilization such as compost, sewage sludge and straw mulch, and decreases with soil tillage (Crecchio et al., 2004; Kizilkaya and Bayrakli, 2005; Meyer et al., 2015). Furthermore, urease activity increased in four different vineyard soils treated with winery wastewater rather than municipal water (Mulidzi and Wooldridge, 2016). The increase in urease activity recorded under organic fertilization shows the close relationship this enzyme shares with soil organic matter and $\mathrm{N}$ cycling. On the other hand, there was a decrease in the activity of urease in soils with long-term nitrogen fertilization, in comparison with unfertilized soils (Mohammadi, 2011). The reduction in urease activity was a result of the absorption of mineral $\mathrm{N}$ by soil microorganisms (Meysner et al., 2006), which supports the hypothesis of Konig et al. (1996) that high quantities of ammonia reduce urease activity. Urease activity can be used to effectively evaluate changes in soil quality relating to management, since its activity increases with organic fertilization and decreases with soil tillage.

Urease activities have effectively discriminated between a wide range of soil management practices. Due to its sensitivity and capacity to provide information that integrates environmental factors and $\mathrm{N}$ cycling, urease activity can be a useful tool to assess soil fertility. Analysis of urease activity can inform management methods that best improve microbial metabolism and $\mathrm{N}$ cycling. Furthermore, urease activity could be stimulated by legume crops since they have the ability to biologically fix N (Roldan et al., 2003). More studies on urease activity and factors affecting them in soils managed with legume crops will provide better ways to minimize the application of urea fertilizer, reduce $\mathrm{NH}_{3}$ loss, and optimize soil nitrogen levels.

\section{Conclusions}

Soil enzymes have been successfully used as indicators of soil quality in different agricultural systems. A better understanding of the function of soil enzymes and the factors influencing their activity is crucial for improving soil management, soil quality, and food production. Soil enzymes catalyze and facilitate decomposition and nutrient cycling, thereby rendering their activities a biological index of soil quality. The soil enzymes are operationally practical, integrative, easy to measure, and they respond to soil management changes long before other soil quality indicator changes are detectable. Their activities may be influenced by soil depth and type, temperature, moisture, $\mathrm{pH}$, the quality and quantity of available substrate, as well as management regimes. Individual enzyme activity does not reflect soil quality status since single enzyme activities cannot represent the rate of all metabolic processes (unless they catalyze one specific reaction). Thus, several enzyme activities should be assessed in order to measure soil quality effectively.

\section{Acknowledgements}

This paper was supported by the Cape Peninsula University of Technology (CPUT) University Research Fund (URF RE86) 


\section{References}

Abbott, L.K., Murphy, D.V. 2003. Soil biological fertility: A key to sustainable land use in agriculture. Springer Science \& Business Media.

Acosta-Martinez, V., Klose, S., Zobeck, T. 2003a. Enzyme activities in semiarid soils under conservation reserve program, native rangeland, and cropland. Journal of Plant Nutrition and Soil Science. $166,699-707$.

Acosta-Martinez, V., Tabatabai, M. 2000. Enzyme activities in a limed agricultural soil. Biology and Fertility of Soils. 31, 85-91.

Acosta-Martinez, V., Zobeck, T., Gill, T., Kennedy, A. 2003b. Enzyme activities and microbial community structure in semiarid agricultural soils. Biology and Fertility of Soils. 38, 216-227.

Alef, K., Nannipieri, P. 1995. Methods in applied soil microbiology and biochemistry. Academic press.

Almeida, R.F.D., Naves, E.R., Mota, R.P.D. 2015. Soil quality: Enzymatic activity of soil $\beta$-glucosidase. Global Journal of Agricultural Research and Reviews. 3, 146-150.

Balezentiene, L. 2012. Hydrolases related to C and N cycles and soil fertility amendment: Responses to different management styles of agro-ecosystems. Pol. J. Environ. Stud. 21, 1153-1159.

Balota, E.L., Chaves, J.C.D. 2010. Enzymatic activity and mineralization of carbon and nitrogen in soil cultivated with coffee and green manures. Revista Brasileira de Ciência do Solo. 34, 1573-1583.

Bandick, A.K., Dick, R.P. 1999. Field management effects on soil enzyme activities. Soil Biology and Biochemistry. 31, 1471-1479.

Banerjee, A., Sanyal, S., Sen, S. 2012. Soil phosphatase activity of agricultural land: A possible index of soil fertility. Agricultural Science Research Journals. 2, 412-419.
Bautista-Cruz, A., Ortiz-Hernandez, Y.D. 2015. Hydrolytic soil enzymes and their response to fertilization: A short review. Comunicata Scientiae. 6,255 .

Binkley, D., Fisher, R. 2012. Ecology and management of forest soils. John Wiley \& Sons.

Blonska, E., Lasota, J. 2014. Biological and biochemical properties in evaluation of forest soil quality. Folia Forestalia Polonica. 56, 23-29.

Condron, L.M., Turner, B.L., Cade-Menun, B.J., Sims, J., Sharpley, A. 2005. Chemistry and dynamics of soil organic phosphorus. Phosphorus: Agriculture and the environment. 87-121.

Corstanje, R., Schulin, R., Lark, R. 2007. Scale-dependent relationships between soil organic carbon and urease activity. European Journal of Soil Science. 58, 1087-1095.

Crecchio, C., Curci, M., Pizzigallo, M.D., Ricciuti, P., Ruggiero, P. 2004. Effects of municipal solid waste compost amendments on soil enzyme activities and bacterial genetic diversity. Soil Biology and Biochemistry. 36, 1595-1605.

Criquet, S., Braud, A., Nèble, S. 2007. Short-term effects of sewage sludge application on phosphatase activities and available $\mathrm{p}$ fractions in mediterranean soils. Soil Biology and Biochemistry. 39, 921-929.

Das, S.K., Varma, A. 2010. Role of enzymes in maintaining soil health. Soil enzymology. Springer.

Dick, W., Cheng, L., Wang, P. 2000. Soil acid and alkaline phosphatase activity as ph adjustment indicators. Soil Biology and Biochemistry. 32, 1915-1919.

Dodor, D.E., Tabatabai, M.A. 2003. Effect of cropping systems on phosphatases in soils. Journal of Plant Nutrition and Soil Science. 166, 7-13. 
Doran, J., Parkin, T. 1994. Defining and assessing soil quality. In 'defining soil quality for a sustainable environment'.(eds jw doran, dc coleman, de bezdicek, ba stewart) pp. 3-21. Soil Science Society of America: Madison, WI, USA.

Eivazi, F., Tabatabai, M. 1990. Factors affecting glucosidase and galactosidase in soils. Soil Biology and Biochemistry. 22, 891-897.

Fioretto, A., Papa, S., Curcio, E., Sorrentino, G., Fuggi, A. 2000. Enzyme dynamics on decomposing leaf litter of cistus incanus and myrtus communis in a mediterranean ecosystem. Soil Biology and Biochemistry. 32, 1847-1855.

Follmer, C. 2008. Insights into the role and structure of plant ureases. Phytochemistry. 69, 18-28.

Fraser, F.C., Hallett, P.D., Wookey, P.A., Hartley, I.P., Hopkins, D.W. 2013. How do enzymes catalysing soil nitrogen transformations respond to changing temperatures? Biology and Fertility of Soils. 49, 99-103.

Garcia-Gil, J., Plaza, C., Soler-Rovira, P., Polo, A. 2000. Long-term effects of municipal solid waste compost application on soil enzyme activities and microbial biomass. Soil Biology and Biochemistry. 32, 1907-1913.

Geiger, G., Federer, P., Sticher, H. 1993. Reclamation of heavy metal — contaminated soils: Field studies and germination experiments. Journal of Environmental Quality. 22, 201-207.

Geisseler, D., Horwath, W.R., Joergensen, R.G., Ludwig, B. 2010. Pathways of nitrogen utilization by soil microorganisms-a review. Soil Biology and Biochemistry. 42, 2058-2067.

Gianfreda, L. 2015. Enzymes of importance to rhizosphere processes. Journal of Soil Science and Plant Nutrition. 15, 283-306.

Gianfreda, L., Bollag, J., Stotzky, G. 1996. Influence of natural and anthropogenic factors on enzyme activity in soil. Soil Biochemistry. 9, 123-193.
Gil-Sotres, F., Trasar-Cepeda, C., Leirós, M., Seoane, S. 2005. Different approaches to evaluating soil quality using biochemical properties. Soil Biology and Biochemistry. 37, 877-887.

Green, V., Stott, D., Cruz, J., Curi, N. 2007. Tillage impacts on soil biology activity and aggregation in a brazillian cerrado oxisol. Soil and Tillage Research. 92, 114-121.

Joner, E., Jakobsen, I. 1995. Growth and extracellular phosphatase activity of arbuscular mycorrhizal hyphae as influenced by soil organic matter. Soil Biology and Biochemistry. 27, 1153-1159.

Kai, M., Takazumi, K., Adachi, H., Wasaki, J., Shinano, T., Osaki, M. 2002. Cloning and characterization of four phosphate transporter cdnas in tobacco. Plant Science. 163, 837-846.

Kalembasa, S., Symanowicz, B. 2012. Enzymatic activity of soil after applying various waste organic materials, ash, and mineral fertilizers. Polish Journal of Environmental Studies. 21, 16351641 .

Kandeler, F., Kampichler, C., Horak, O. 1996. Influence of heavy metals on the functional diversity of soil microbial communities. Biology and Fertility of Soils. 23, 299-306.

Karaca, A., Cetin, S.C., Turgay, O.C. Kizilkaya, R. 2010. Soil enzymes as indication of soil quality. Soil enzymology. Springer.

Kizilkaya, R., Bayrakli, B. 2005. Effect of n-enriched sewage sludge on soil enzyme activities. Applied Soil Ecology. 30, 192-202.

Konig, C., Kaltvasser, H., Schiegel, H. 1996. The formation of urease after use of other nitrogen sources in hidrogenumonas. Archives of Microbiology. 53, 231-241.

Lemanowicz, J. 2011. Phosphatases activity and plant available phosphorus in soil under winter wheat (triticum aestivum 1.) fertilized minerally. Polish Journal of Agronomy. 4, 12-15. 
Liu, Y., Mi, G., Chen, F., Zhang, J., Zhang, F. 2004. Rhizosphere effect and root growth of two maize (zea mays 1.) genotypes with contrasting $\mathrm{p}$ efficiency at low p availability. Plant Science. 167, 217-223.

Machuca, A., Cuba-Díaz, M., Córdova, C. 2015. Enzymes in the rhizosphere of plants growing in the vicinity of the polish arctowski antarctic station. Journal of soil science and plant nutrition. 15, 833-838.

Makoi, J.H., Chimphango, S.B., Dakora, F.D. 2010. Elevated levels of acid and alkaline phosphatase activity in roots and rhizosphere of cowpea (vigna unguiculata 1. Walp.) genotypes grown in mixed culture and at different densities with sorghum (sorghum bicolar 1.) Crop and Pasture Science. 279-286.

Makoi, J.H., Ndakidemi, P.A. 2008. Selected soil enzymes: Examples of their potential roles in the ecosystem. African Journal of Biotechnology. 7.

Martinez, C., Tabatabai, M. 1997. Decomposition of biotechnology by-products in soils. Journal of Environmental Quality. 26, 625-632.

Maseko, S. Dakora, F. 2013. Rhizosphere acid and alkaline phosphatase activity as a marker of p nutrition in nodulated cyclopia and aspalathus species in the cape fynbos of south africa. South African Journal of Botany, 89, 289-295.

Matsuoka, M., Mendes, I., Loureiro, M. 2003. Microbial biomass and enzyme activities in soils under native vegetation and annual and perennial agricultural systems in primavera do leste region $(\mathrm{mt})$. Journal of Soil Science. 27, 425-433.

Merino, C., Godoy, R., Matus, F. 2016. Soil enzymes and biological activity at different levels of organic matter stability. Journal of Soil Science and Plant Nutrition. 16, 14-30.
Meyer, A.H., Wooldridge, J., Dames, J.F. 2015. Variation in urease and $\beta$-glucosidase activities with soil depth and root density in a 'cripp's pink'/ $\mathrm{m} 7$ apple orchard under conventional and organic management. South African Journal of Plant and Soil. 32, 227-234.

Meysner, T., Szajdak, L., Ku, J. 2006. Impact of the farming systems on the content of biologically active substances and the forms of nitrogen in the soils. Agronomy Research. 4, 531-542.

Miralles, I., Ortega, R., Almendros, G., Gil-Sotres, F., Trasar-Cepeda, C., Leirós, M., Soriano, M. 2012. Modifications of organic matter and enzymatic activities in response to change in soil use in semi-arid mountain ecosystems (southern spain). European Journal of Soil Science. 63, 272-283.

Mobley, H., Island, M.D., Hausinger, R.P. 1995. Molecular biology of microbial ureases. Microbiological Reviews. 59, 451-480.

Mohammadi, K. 2011. Soil microbial activity and biomass as influenced by tillage and fertilization in wheat production. American-Eurasian Journal Agricultural \& Environmental Sciences Deira. 10, 330-337.

Mukumbareza, C., Chiduza, C., Muchaonyerwa, P. 2015. Effects of oats and grazing vetch cover crops and fertilisation on microbial biomass and activity after five years of rotation with maize. South African Journal of Plant and Soil. 32, 189197.

Mukumbareza, C., Muchaonyerwa, P., Chiduza, C. 2016. Bicultures of oat (avena sativa 1.) and grazing vetch (vicia dasycarpa 1.) cover crops increase contents of carbon pools and activities of selected enzymes in a loam soil under warm temperate conditions. Soil Science and Plant Nutrition. 62, 447-455. 
Mulidzi, A.R., Wooldridge, J. 2016. Effect of irrigation with diluted winery wastewater on enzyme activity in four western cape soils. Sustainability in Environment. 1, 141.

Nannipieri, P., Giagnoni, L., Landi, L., Renella, G. 2011. Role of phosphatase enzymes in soil. Phosphorus in action. Springer.

Nannipieri, P., Giagnoni, L., Renella, G., Puglisi, E., Ceccanti, B., Masciandaro, G., Fornasier, F., Moscatelli, M.C., Marinari, S. 2012. Soil enzymology: Classical and molecular approaches. Biology and Fertility of Soils. 48, 743-762.

Nannipieri, P., Gianfreda, L., Huang, P., Senesi, N. Buffle, J. 1998. Kinetics of enzyme reactions in soil environments. Structure and surface reactions of soil particles. 449-479.

Ndakidemi, P.A. 2006. Manipulating legume/cereal mixtures to optimize the above and below ground interactions in the traditional african cropping systems. African Journal of Biotechnology. 5.

Pandey, D., Agrawal, M., Bohra, J.S. 2014. Effects of conventional tillage and no tillage permutations on extracellular soil enzyme activities and microbial biomass under rice cultivation. Soil and Tillage Research. 136, 51-60.

Piotrowska-Dlugosz, A., Charzynski, P. 2015. The impact of the soil sealing degree on microbial biomass, enzymatic activity, and physicochemical properties in the ekranic technosols of torun (poland). Journal of Soils and Sediments. 15, 47-59.

Piotrowska-Dlugosz, A., Wilczewski, E. 2014a. Changes in enzyme activities as affected by greenmanure catch crops and mineral nitrogen fertilization. Zemdirbyste (Agriculture). 101, 139-146.

Piotrowska-Dlugosz, A., Wilczewski, E. 2014b. Soil phosphatase activity and phosphorus content as influenced by catch crops cultivated as green manure. Polish Journal of Environmental Studies. 23, 157.
Piotrowska, A., Wilczewski, E. 2012. Effects of catch crops cultivated for green manure and mineral nitrogen fertilization on soil enzyme activities and chemical properties. Geoderma. 189, 72-80.

Rietz, D., Haynes, R. 2003. Effects of irrigation-induced salinity and sodicity on soil microbial activity. Soil Biology and Biochemistry. 35, 845-854.

Roldan, A., Caravaca, F., Hernandez, M., García, C., Sanchez-Brito, C., Velasquez, M., Tiscareno, M. 2003. No-tillage, crop residue additions, and legume cover cropping effects on soil quality characteristics under maize in patzcuaro watershed (mexico). Soil and Tillage Research. 72, 65-73.

Saha, S., Prakash, V., Kundu, S., Kumar, N., Mina, B.L. 2008. Soil enzymatic activity as affected by long term application of farm yard manure and mineral fertilizer under a rainfed soybean-wheat system in nw himalaya. European Journal of Soil Biology. 44, 309-315.

Sardans, J., Penuelas, J. 2005. Drought decreases soil enzyme activity in a mediterranean quercus ilex 1. Forest. Soil Biology and Biochemistry. 37, 455-461.

Sinsabaugh, R.L., Lauber, C.L., Weintraub, M.N., Ahmed, B., Allison, S.D., Crenshaw, C., Contosta, A.R., Cusack, D., Frey, S., Gallo, M.E. 2008. Stoichiometry of soil enzyme activity at global scale. Ecology Letters. 11, 1252-1264.

Srivastava, P.K., Gupta, M., Upadhyay, R.K., Sharma, S., Singh, N., Tewari, S.K., Singh, B. 2012. Effects of combined application of vermicompost and mineral fertilizer on the growth of allium cepa 1. And soil fertility. Journal of Plant Nutrition and Soil Science. 175, 101-107.

Staddon, W., Duchesne, L., Trevors, J. 1998. Acid phosphatase, alkaline phosphatase and arylsulfatase activities in soils from a jack pine (pinus banksiana lamb.) ecosystem after clear-cutting, prescribed burning, and scarification. Biology and Fertility of Soils. 27, 1-4. 
Tabatabai, M. 1994. Soil enzymes. Methods of Soil Analysis: Part 2-Microbiological and Biochemical Properties. 775-833.

Utobo, E., Tewari, L. 2015. Soil enzymes as bioindicators of soil ecosystem status. Applied Ecological Environmental Research. 13, 147-169.

Van Aarle, I.M., Plassard, C. 2010. Spatial distribution of phosphatase activity associated with ectomycorrhizal plants is related to soil type. Soil Biology and Biochemistry. 42, 324-330.

Veena, V., Poornima, P., Parvatham, R., Sivapriyadharsini Kalaiselvi, K. 2011. Isolation and characterization of $\beta$-glucosidase producing bacteria from different sources. African Journal of Biotechnology. 10, 14907-14912.
Verdoucq, L., Czjzeck, M., Moriniere, J., Bevan, D.R. Esen, A. 2003. Mutational and structural analysis of aglycone specificity in maize and sorghum $\beta$ -glucosidases. Journal of Biological Chemistry. 278, 25055-25062.

Xiao-Chang, W., Qin, L. 2006. Beta-glucosidase activity in paddy soils of the taihu lake region, china. Pedosphere. 16, 118-124.

Yang, Z.X., Liu, S.Q., Zheng, D.W. Feng, S.D. 2006. Effects of cadium, zinc and lead on soil enzyme activities. Journal of Environmental Sciences. 18, 1135-1141.

Zhang, Y., Chen, L., Wu, Z., Sun, C. 2011. Kinetic parameters of soil $\beta$-glucosidase response to environmental temperature and moisture regimes. Revista Brasileira de Ciência do Solo. 35, 1285-1291. 